\title{
MODULATORY EFFECTS OF DIETARY SUPPLEMENTATION BY VERNONIA AMYGDALINA ON HIGH-FAT-DIET-INDUCED OBESITY IN WISTAR RATS
}

\author{
Chima A. Ekeleme-Egedigwe ${ }^{1 \bowtie}$, Ifeoma I. Ijeh², Polycarp N. Okafor ${ }^{2}$ \\ ${ }^{1}$ Department of Chemistry/Biochemistry, Federal University Ndufu Alike \\ Ikwo, PMB 1010, Abakaliki, Ebonyi State, Nigeria \\ ${ }^{2}$ Department of Biochemistry, College of Natural Sciences, Michael Okpara University of Agriculture \\ Umudike, PMB 7267, Umuahia, Abia State, Nigeria
}

\begin{abstract}
Background. Obesity is a growing public health problem arising from energy imbalance. The effect of $10 \%$ dietary incorporation of Vernonia amygdalina (VA) leaves into high-fat diets on some biological markers of adiposity and dyslipidaemia was investigated.

Methods. Experimental diets consisted of the following - CD (control diet); HFD (high-fat diet); and HFDVA (HFD containing 10\% Vernonia amygdalina leaves) supplementation. Fifteen male Wistar rats were randomly divided into three groups of five animals each. After twelve weeks of feeding, serum lipid profile, blood glucose concentrations, body weight, adiposity index, feed intake, fecal loss and relative organ weight were investigated.

Results. Vernonia amygdalina (VA) inhibited HFD-induced weight gain and adiposity in rats. HFD-induced obese rats showed a significant increase in the levels of serum TG and TC compared to rats on a normal diet. However, the levels of serum TG, TC, LDL-C in HFDVA rats reduced significantly relative to the levels in HFD rats. Our results indicate that HFDVA reversed fatty infiltration leading to decreased body weight and fat tissue mass in the rats.

Conclusion. These results suggested that incorporation of Vernonia amygdalina into high-fat diets may have therapeutic potentials for obesity and related metabolic disorders. Further studies to explore its possibility as an alternative pharmacologic agent to treat obesity are warranted.
\end{abstract}

Keywords: Vernonia amygdalina, antiobesity, high-fat diet, lipid profile, adiposity

\section{INTRODUCTION}

Obesity is a global epidemic which is one of the leading non-communicable diseases leading to vascular diseases (Ong et al., 2017). Obesity results from an imbalance between food intake and energy expenditure (Balaji et al., 2015), which results in the accumulation of fat in the adipose tissue, liver, muscle and certain organs used in metabolism. Being obese and overweight predisposes an individual to a number of diseases, including cardiovascular diseases, coronary artery, hypertension, type 2 diabetes mellitus, sleep apnea, fatty liver, osteoarthritis, gallbladder disease and some types of cancer (WHO, 2012). Nigeria is the most populous developing country in Africa, with increasing changes in lifestyle and an associated increasing 
burden of non-communicable diseases (Chukwuonye et al., 2013a). Obesity is a growing health problem in the Western world as well as in Africa. Nigeria, like other Sub-Saharan African countries, is also facing a shift in dietary patterns from indigenous nutritious foods to cafeteria diets with a concomitant increase in the number of overweight individuals. Food choices which include poor nutritional habits, increased consumption of more energy-dense, nutrient-poor foods, with high levels of sugar and saturated fats, combined with reduced physical activity, have led to increased rates of the incidence of obesity in many parts of the world (Chukwuonye et al., 2013b).

Bioactive components from various medicinal plants could act as potential drugs useful in obesity management. Research findings show that polyphenols such as apigenin, genistein and the catechins have strong anti-obesity activity (Rayalam et al., 2008; Thielecke and Boschmann, 2009; Wolfram et al., 2006). Moreover, polyphenols have been reported to prevent oxidative damage that occurs as a consequence of a high-fat diet (Charradi et al., 2014). Several studies have also shown that dietary saponins may reduce obesity and hyperlipidemia (Francis et al., 2002; Lee et al., 2005; Yoshizumi et al., 2006; WHO, 1999). Ijeh et al. (2014) reported that administration of crude saponins from $V$. amygdalina resulted in significant weight loss in experimental rats. In an earlier report Igile et al. (1995) observed a significant weight loss in rats administered purified saponins from $V$. amygdalina leaves. A variety of natural products, including crude extracts and isolated compounds from plants, have gained acceptance as slimming agents (Han et al., 2005a; Moro and Basile, 2000). Previous studies carried out on non-obese rats fed unprocessed Vernonia amygdalina at $10 \%$ of dietary incorporation showed significant weight loss in albino rats (Egedigwe and Ijeh, 2010b; Ijeh and Akomas, 2005; Ijeh and Obidoa, 2001; Ijeh et al., 2014). The obesity epidemic has led to an intensified search for anti-obesity agents and the approved drugs exhibit undesirable side effects and are expensive (Abdollahi and Afshar-Imani, 2003; Mistry et al., 2011). Licensed drugs (Orlistat, Lorcaserin and Phentermine-topiramate) used for the management of obesity are ideal when used in conjunction with diet, exercise and behavioral-change regimens. However, they do not cure obesity and are associated with weight rebounds when these drugs are discontinued, hence the screening for medicinal plants with bioactive agents that could be better tolerated, safe and more efficacious are used to curb the obesity epidemic (Yun, 2010).

Vernonia amygdalina (VA) is a dark green leafy vegetable with a characteristic odour and taste that is commonly used for food and medicinal purposes in Africa, especially in Nigeria. The bitter leaf is called "omjunso" in East Africa especially Tanzania, "onugbo" in Igbo-Eastern Nigeria and "orugbo" among the Itsekiri and Urhobo tribes in Nigeria, "ewuro" (Yoruba), "etidot" (Ibibio), "ityuna" (Tiv), "oriwo" (Edo), 'kiriologbo' in Ijaw (Izon), "chusa-doki shiwaka" (Hausa), "omubirizi" or "omululuza" (West and Central Uganda) and "olusia" (Luo, Kenya) (Agbogidi and Akpomorine, 2013; Egedigwe, 2010). In Cameroun, its leaves are used to prepare a delicacy called "ndole", while in Nigeria, this leafy vegetable can be sold fresh or dried and are also a typical ingredient used to prepare delicacies such as "ofe onugbu" and "ofe ogbono", popularly called "egusi" soup and "ogbono" soup respectively. Vernonia amygdalina requires some forms of processing to remove its bitterness before consumption and this can be achieved by washing in several changes of water. The leaves of Vernonia amygdalina can be found as shrubs in homesteads and grown around houses in Nigeria, which are even served in place of kolanuts to welcome guests in the south-eastern region of Nigeria. The nutritional and medicinal uses of Vernonia amygdalina has been extensively documented in reviews by Ijeh and Ejike (2011) and Farombi and Owoeye (2011), respectively. Its ethnomedicinal use in the management of dyslipidaemic conditions makes it a potential candidate for screening its anti-obesity potential. This study therefore examines the effect of dietary incorporation of Vernonia amygdalina into high-fat diets on biological markers of adiposity and dyslipidaemia.

\section{MATERIALS AND METHODS}

Fresh leaves were harvested around farms at Michael Okpara University of Agriculture, Umudike, Abia State. A voucher specimen was authenticated in the Taxonomy Department with herbarium number (FHI 28786) designated for Vernonia amygdalina. Fifteen 
albino rats of Wistar strain weighing $95-110 \mathrm{~g}$ were purchased from the Animal Breeding Unit of the Faculty of Veterinary Medicine, University of Nigeria, Nsukka, gently handled and transported to the Animal Breeding Unit of the Department of Biochemistry, Michael Okpara University of Agriculture, Umudike. They were housed in stainless steel cages with plastic bases and acclimatized for 2 weeks on Vital Growers mash and water ad libitum. The animals were randomly divided into three groups of five animals each and experiments were performed for 12 weeks. In these animal experiments, the authors certify that they were carried out in accordance with the National Institute of Health Guide for the Care and Use of Laboratory Animals (NIH..., 1996).

All feeding materials were locally sourced from a commercial Agro Feed retailer in Abia State. The basal diet (control) consisted of the same feed stuff as HFDs, excluding palm kernel oil, palm oil and egg yolk powder as listed in Table 1. Feed constituents were accurately weighed into a clean bowl using an electronic balance and then mixed thoroughly. The diets were then converted to pellets by extrusion through an improvised device and dried in an oven at a temperature of $30^{\circ} \mathrm{C}$. Pelleted diets were provided to all animals by means of pair feeding in their respective cages. The HFD was designed in such a way that $35 \%$ of the total energy in the diet was derived from fats.

Determination of adiposity index. The adiposity index of the animals was measured using the Lee index of obesity in animals, because it is highly correlated with the percentage of total body fat. The Lee index is expressed as a cubic root of body weight in grams divided by the naso-anal length in millimeters multiplied by $10^{3}$ (Lee, 1929).

\section{Body weight change:}

body weight $=\{$ final body weight - initial body weight $\}$ / final body weight $\times 100$

Relative organ weight: organ weight / final body weight $\times 100$

Food intake:

Food intake, $\mathrm{g}=$ total feed provided daily, $\mathrm{g}-$ total feed remaining daily, $\mathrm{g}$

Fecal loss calculation:

daily total fecal bulk / number of animals in group

Table 1. Compounded diets of formulated feeds, $\mathrm{g} / 100 \mathrm{~g}$

\begin{tabular}{lrrr}
\hline & CD & HFD & HFDVA \\
\hline Maize & 66.66 & 38.88 & 38.88 \\
Groundnut cake & 8.93 & 13.39 & 13.39 \\
Fish meal & 2.88 & 2.16 & 2.16 \\
Vitamin/minerals & 1.07 & 1.98 & 1.98 \\
Bone meal & 1.08 & 1.98 & 1.98 \\
Palm oil & 0.00 & 6.95 & 6.95 \\
Palm kernel oil & 0.00 & 6.95 & 6.95 \\
Egg yolk powder & 0.00 & 5.84 & 5.84 \\
Non nutritive cellulose & 0.21 & 0.40 & 0.40 \\
Corn starch & 19.17 & 21.45 & 21.45 \\
Vernonia amygdalina & 0.00 & 0.00 & 10.00 \\
\hline
\end{tabular}

CD - control diet, HFD - high-fat diet, HFDVA - high-fat diet with Vernonia amygdalina. 
After twelve weeks of feeding, the animals were euthanized humanely and blood samples were collected by cardiac puncture from a bleeding heart, following a 12-hour fast. Blood samples were analyzed for the following biochemical estimations: lipid profile, blood glucose, insulin and leptin concentrations.

Fasting blood glucose concentration. This was analyzed using Accu-Check Active Glucometer and test strips supplied by Roche Diagnostics GmbH, Mannheim, Germany (D’Orazio et al., 2005).

Lipid profile estimation. Component lipids (cholesterol, HDL-C and triacylglycerol concentrations) were estimated using standard commercial test kits supplied by RANDOX Laboratories using the enzymatic colorimetric methods described by Tietz (1990), Allain et al. (1974) and Lopes-Virella et al. (1977). A very lowdensity lipoprotein cholesterol (VLDL-C) concentration was estimated using the formula: VLDL cholesterol $=$ triacylglycerol concentration $[\mathrm{mg} / \mathrm{dL}] / 5$, while low-density lipoprotein cholesterol (LDL-C) concentrations were estimated by the difference (Friedewald et al., 1972).

\section{Assessment of atherogenic and coronary risk index}

The atherogenic index and coronary risk index were calculated by formulae LDL-C/HDL-C and TC/HDL-C, respectively (Abbot et al., 1988).

Insulin and leptin estimation. Serum insulin and leptin concentrations were determined by the enzymatic immunoassay methods as described in the EIA kits procured from Bertin Pharma, Montigny-le-Bretonneux,
France. For all estimations, the manufacturer's instructions were strictly followed.

Histhopathological studies. Sections of liver from each group were collected in a sterile universal container containing a $10 \%$ formal saline solution. Histology studies were properly carried out according to Singh (2006) and Mohan (2007). Staining was performed using Harry's Haematoxylin and Eosin (H\&E) procedures. Photomicrographs were taken using a computer with a Microscopic Analysis Software (Scope Image-9.0) connected to an Olympus digital light microscope (Olympus UK Ltd, Essex UK). The fixed slides were viewed under a light microscope and photomicrographs were captured $(\times 400)$.

\section{Statistical analysis}

Data was analyzed using SPSS Version 20.0 (IBM SPSS Inc., Chicago, IL) software. All values were expressed as the mean \pm standard deviation (mean $\pm \mathrm{SD}$ ). One-way analysis of variance (ANOVA) was used for the comparison of means. The results were considered to be significant when $P<0.05$.

\section{RESULTS AND DISCUSSION}

Adiposity levels decreased $(p<0.05)$ significantly in groups (CD and HFDVA) relative to the HFD group as seen in Table 2. According to the Lee index of assessing obesity in animals, values up to 300 and above are classified as obese. The high-fat diets (HFDs) used in this study may have acted as a source of saturated fat, resulting in excessive energy supply and therefore increased body weight. Scientific studies have also shown that fat-rich diets induce obesity by increasing

Table 2. Effect of diet supplementation on food intake, fecal loss and Lee index of obesity

\begin{tabular}{lccc}
\hline \multicolumn{1}{c}{ Groups } & Food intake, $\mathrm{g}$ & Fecal loss, $\mathrm{g}$ & Lee index, $\mathrm{g} / \mathrm{cm}^{3}$ \\
\hline CD & $11.41 \pm 1.41^{\mathrm{a}}$ & $4.84 \pm 0.48^{\mathrm{b}}$ & $197.95 \pm 5.00^{\mathrm{b}}$ \\
HFD & $11.53 \pm 1.46^{\mathrm{a}}$ & $2.95 \pm 0.35^{\mathrm{c}}$ & $370.45 \pm 4.55^{\mathrm{a}}$ \\
HFDVA & $11.19 \pm 1.41^{\mathrm{a}}$ & $6.20 \pm 0.70^{\mathrm{a}}$ & $186.18 \pm 6.55^{\mathrm{c}}$ \\
\hline
\end{tabular}

Means in the same column with different superscript are significantly different at $p<0.05$. CD - control diet, HFD - high-fat diet, HFDVA - high-fat diet with Vernonia amygdalina. 
energy stores, which is due to the increased energy supply from the high energy density of the HFDs (Ghibaudi et al., 2002; Harrold et al., 2000). Consumption of HFDs could enhance a positive energy balance resulting in weight gain, an increase in fatty tissue (through conversion of excess energy to lipids and its accumulation as triglycerides in the fat depots) and obesity. There was no significant difference in feed intake in all groups fed the various diets as shown in Table 2. Comparing the feed intake between both experimental groups fed HFDs and HFDVA also showed no significant difference for all the weeks studied. Despite the characteristic bitter taste of VA leaves, feed intake was not affected when Vernonia amygdalina was incorporated into diets, suggesting that the weight loss was not attributable to reduced feed acceptability and intake. Our results are in agreement with reports by Atangwho et al. (2012), who reported unaffected feed intake and antiobesity effect of Vernonia amygdalina supplemented cafeteria diets. Vernonia amygdalina has been reportedly fed to broilers, where it replaced $300 \mathrm{~g} \cdot \mathrm{kg}^{-1}$ of a maize-based diet without affecting feed intake, body weight gain and feed efficiency (Bonsi et al., 1995; Teguia et al., 1993). There was a significant $(p<0.05)$ increase in fecal loss deposits observed in animals fed HFDVA relative to the groups fed HFD and $\mathrm{CD}$, as shown in Table 2. The higher fecal deposits could be attributed to the high fiber content of the leaves of Vernonia amygdalina. Egedigwe (2015) reported decreased pancreatic lipase and amylase activity, indicating that the extracts from Vernonia amygdalina exhibited inhibitory effects on enzymes involved in digestion, decreasing nutrient utilization and hence fecal bulk. Studies in animals have shown that the high level of dietary fiber in leafy vegetables is advantageous for their active role in the regulation of intestinal transit, increasing dietary bulk and feces consistency due to ability to absorb water (Jenkin et al., 1986). These findings are consistent with reports that supplementation of Vernonia amygdalina in diets increased urinary and fecal output in mice and rats (Igile et al., 1995). High-fat diets with Vernonia amygdalina (HFDVA) showed a significant $(p<0.05)$ decrease in body weight relative to the groups fed high-fat diets (HFD) only as shown in Table 3. It is indicative that the incorporation of Vernonia amygdalina in the HFDs may have resulted in the inhibition of high-fat-diet-induced body gain. Vernonia amygdalina is rich in saponins (Ijeh et al., 1996), which are known to affect body weight gain by several mechanisms and recent studies by Ijeh et al. (2014) reported body weight loss when crude saponins isolated from Vernonia amygdalina were administered to albino rats. Anti-obesity effects have been reported in animals exposed to saponins isolated from Platycodix radix (Han et al., 2002), Panax japonicas (Han et al., 2005b) and Panax ginseng (Karu et al., 2007). The observation in this study is consistent with our earlier reports (Egedigwe and Ijeh, 2010b) and that of other researchers (Atangwho et al., 2007a; Igile et al., 1995) in non-obese experimental animals administered $V$. amygdalina either as extracts (Ibrahim et al., 2000) or supplemented in their diets (Atangwho et al., 2007b). Furthermore, there was no significant difference between body weight gain in the control and HFDVA groups. This suggests that incorporating VA into the diets of HFD served as an effective control agent against diet-induced lipogenesis. Table 4 shows the relative liver, intestine, kidney, heart and fat pad weights in albino rats fed control, HFD and HFDVA.

Table 3. Body weight and percentage change in animals fed control, HFD and HFDVA diet

\begin{tabular}{lccc}
\hline \multicolumn{1}{c}{ Groups } & Initial body weight, $g$ & Final body weight, $g$ & Change, $\%$ \\
\hline CD & $183.68 \pm 11.65^{\mathrm{a}}$ & $240.78 \pm 11.50^{\mathrm{b}}$ & 23.71 \\
HFD & $185.67 \pm 10.00^{\mathrm{a}}$ & $305.35 \pm 12.60^{\mathrm{a}}$ & 39.19 \\
HFDVA & $186.79 \pm 11.50^{\mathrm{a}}$ & $240.43 \pm 12.00^{\mathrm{b}}$ & 22.31 \\
\hline
\end{tabular}

Means in the same column with different superscript are significantly different at $p<0.05$. CD - control diet, HFD - high-fat diet, HFDVA - high-fat diet with Vernonia amygdalina. 
Ekeleme-Egedigwe, C. A., ljeh, I. I., Okafor, P. N. (2017). Modulatory effects of dietary supplementation by Vernonia amygdalina on high-fat-diet-induced obesity in Wistar rats. Acta Sci. Pol. Technol. Aliment., 16(4), 431-442. http://dx.doi.org/10.17306/J. AFS.2017.0504

Table 4. Relative organ weights in Wistar rats fed HFD, HFDVA and control diet

\begin{tabular}{lccccc}
\hline \multicolumn{1}{c}{ Groups } & Liver & Kidney & Intestine & Spleen & Fat pads \\
\hline HFD & $3.21 \pm 2.71 \times 10^{-1 \mathrm{a}}$ & $6.71 \times 10^{-1} \pm 5.59 \times 10^{-2 \mathrm{a}}$ & $5.34 \pm 3.82 \times 10^{-1 \mathrm{a}}$ & $2.06 \times 10^{-1} \pm 2.21 \times 10^{-2 \mathrm{a}}$ & $3.22 \pm 8.71 \times 10^{-1 \mathrm{a}}$ \\
HFDVA & $2.85 \pm 3.64 \times 10^{-1 \mathrm{a}}$ & $6.77 \times 10^{-1} \pm 5.26 \times 10^{-2 \mathrm{a}}$ & $6.57 \pm 2.22^{\mathrm{a}}$ & $1.88 \times 10^{-1} \pm 2.93 \times 10^{-2 \mathrm{a}}$ & $2.80 \pm 8.64 \times 10^{-1 \mathrm{~b}}$ \\
Control & $2.91 \pm 3.55 \times 10^{-1 \mathrm{a}}$ & $6.69 \times 10^{-1} \pm 6.54 \times 10^{-2 \mathrm{a}}$ & $5.65 \pm 2.68^{\mathrm{a}}$ & $1.92 \times 10^{-1} \pm 2.11 \times 10^{-2 \mathrm{a}}$ & $3.05 \pm 7.71 \times 10^{-1 \mathrm{a}}$ \\
\hline
\end{tabular}

Means with same superscript in the same column are considered not significantly different at $p<0.05$.

HFD - high-fat diet, HFDVA - high-fat diet + Vernonia amygdalina.

Relative liver, kidney, spleen and intestinal weights showed no significant difference between the groups fed HFDs and HFDVA relative to the control group. Fat pad mass showed a significant $(p<0.05)$ decrease in the HFDVA group relative to the HFD group, which indicates that the VA incorporated into the diet could effect reverse fatty infiltration, as seen in the histology results. These results show that the level of dietary incorporation of VA leaves could be ascertained to be non-toxic to the various organs investigated. Table 5 shows a significant $(p<0.05)$ decrease in cholesterol and triacylglycerol concentrations in experimental animals fed high-fat diets incorporated with Vernonia amygdalina (HFDVA) relative to the groups fed HFDs and control diets. Dietary cholesterol is known to increase serum total cholesterol, LDL-C, VLDL-C and decrease in HDL-C concentrations. Saponins have been reported to elicit serum cholesterol lowering activity by producing a resin-like action, which decreases enterohepatic circulation of bile acids (Topping et al., 1980). Hypocholesterolaemia can be achieved when the liver enhances the conversion of cholesterol to bile acids (Kritchevsky, 1977; Oakenfull and Sidhu,
1989). Therefore increased consumption of VA compared well with lower cholesterol levels and a reduced risk for heart disease. Thus, Vernonia amygdalina incorporation into diets could inhibit body fat accumulation by reducing cholesterol build-up in the rats. The results and interpretations agree with that of previous findings by Egedigwe et al. (2016a), Akah and Okafor (1992a; 1992b), Adaramoye et al. (2008), Egedigwe and Ijeh (2010a), Atangwho et al. (2012), Ijeh et al. (2014). Several researchers have also reported the hypolipdaemic effects of saponins from Parkia biglbosa leaves (Zhao et al., 2008) and Platycodin grandiflorum (Komolafe et al., 2013). A significant $(p<0.05$ ) decrease in triacylglycerol concentrations was observed in the groups fed HFDVA when compared to the control and HFD groups as shown in Table 4. Therefore, Vernonia amygdalina improves hypertriglyceridemia state and might protect against body fat accumulation that could result to obesity, hence the decreased triacylglycerol concentrations, which act as the source of free fatty acids. Hepatic triglyceride biosynthesis is reduced by leaves of VA and therefore enhances the redistribution of cholesterol among the li-

Table 5. Effect of CD, HFD and HFDVA diets supplementation on lipid profile concentrations, mg/dl

\begin{tabular}{lccccc}
\hline \multicolumn{1}{c}{ Groups } & TC & TG & HDL-C & LDL-C & VLDL-C \\
\hline CD & $100.58 \pm 4.82^{\mathrm{b}}$ & $120.65 \pm 7.43^{\mathrm{b}}$ & $71.45 \pm 5.65^{\mathrm{b}}$ & $15.00 \pm 5.67^{\mathrm{b}}$ & $24.13 \pm 5.09^{\mathrm{b}}$ \\
HFD & $167.29 \pm 3.22^{\mathrm{a}}$ & $228.93 \pm 10.5^{\mathrm{a}}$ & $59.73 \pm 4.77^{\mathrm{c}}$ & $19.77 \pm 3.69^{\mathrm{a}}$ & $45.79 \pm 4.91^{\mathrm{a}}$ \\
HFDVA & $97.71 \pm 4.31^{\mathrm{b}}$ & $112.75 \pm 6.29^{\mathrm{c}}$ & $88.36 \pm 5.29^{\mathrm{a}}$ & $13.20 \pm 4.13^{\mathrm{c}}$ & $22.55 \pm 5.25^{\mathrm{b}}$ \\
\hline
\end{tabular}

Means in the same column with different superscript are significantly different at $p<0.05$.

CD - control diet, HFD - high-fat diet, HFDVA - high-fat diet with Vernonia amygdalina.

TC - total cholesterol, TG - triacylglycerol, HDL-C - high density lipoprotein cholesterol, LDL-C - low density lipoprotein cholesterol, VLDL-C - very low density lipoprotein cholesterol. 
poprotein particles as reported by Adaramoye et al. (2008). This observation is consistent with the findings of Nwanjo (2005), Adaramoye et al. (2008) on extracts of VA. A suggested mechanism of the antiobesity effect of leaves of Vernonia amygdalina in high-fat-diet-fed animals could be attributed to a decrease in triglyceride synthesis and accumulation in the liver attributable to the inhibition of dietary triglyceride digestion and absorption. HDL-cholesterol concentrations was more significantly $(p<0.05)$ increased in groups fed high-fat diets incorporated with Vernonia amygdalina (HFDVA) than in the groups fed high-fat diets (HFDs) and control diets as shown in Table 4. The increased serum HDL cholesterol concentrations observed indicate that leaves of Vernonia amygdalina administered to animals may be beneficial in modulating lipid levels. Vernonia amygdalina probably has an anti-atherogenic role through the inhibition of lipid oxidation, as well as the elevation of HDL cholesterol as reported by Adaramoye et al. (2008). This is in agreement with our previous study Egedigwe and Ijeh (2010b), which reported increased levels of HDL when unprocessed Vernonia amygdali$n a$ was incorporated into diets. HDL has an anti-atherogenic effect by promoting the reverse cholesterol transport pathway by returning to the liver all cholesterol removed from plasma and cells of non-hepatic tissues. On the liver surface, they bind to a receptor called SR-B1 and transfer cholesterol and cholesterol esters into liver cells. The lipid depleted HDL particles return to the plasma. In the liver, the cholesterol can be converted to bile salts, which are secreted into the gall bladder (Yokozawa et al., 2006). Vernonia amygdalina is rich in phytochemicals such as flavonoids, alkaloids and tannins known to possess anti- -oxidative properties (Ijeh et al., 1996). There was a $(p<0.05)$ significant decrease in LDL-C and VLDL-C concentrations in the group fed HFDVA relative to the other groups. LDL cholesterol poses a risk to Cardiovascular Diseases (CVDs), as it transports cholesterol to the arteries, invades the endothelium and becomes oxidized. Obesity is aggravated when LDL cholesterol causes oxidative stress and endothelial damage (Mistry et al., 2011). From this study, it was observed that VA supplementation resulted in a reduction in LDL susceptibility to oxidation and increased the resistance of plasma LDL to oxidation, thereby controlling weight gain in the rats. Thus, increased levels of LDL cholesterol are reported to be associated with artherosclerosis, heart attack, stroke and peripheral vascular diseases (Bordia and Verma, 1998; Cromwell and Otvos, 2004) and could predispose an individual to obesity. The results confirm previous findings by Adaramoye et al. (2008), who reported that extracts of Vernonia amygdalina administered to rats lowered LDL cholesterol of hypercholesterolamic rats. A systematic review on medicinal plants reported that plants possessing anti-diabetic properties and having anti-hyperlipidemic effects could also be significant in the management of obesity (Hasani-Ranjbar et al., 2008). Table 6 shows a significant $(p<0.05)$ decrease in both the atherogenic and coronary risk index in HFDVA relative to animals fed HFD and this strongly confirms the hypolipidemic effect of Vernonia amygdalina leaves. This is in line with earlier reports where rats fed HFDs had increased atherogenic and coronary index reference values (Adeneye et al., 2010). There was a significant $(p<0.05)$ decrease in blood glucose concentrations in rats fed HFDVA relative to the group fed HFD,

Table 6. Effect of diet supplementation on atherogenic index and coronary risk index

\begin{tabular}{lcc}
\hline \multicolumn{1}{c}{ Groups } & Atherogenic index & Coronary risk index \\
\hline CD & $0.24 \pm 0.01^{\mathrm{b}}$ & $1.64 \pm 0.01^{\mathrm{b}}$ \\
HFD & $0.33 \pm 0.02^{\mathrm{a}}$ & $2.80 \pm 0.03^{\mathrm{a}}$ \\
HFDVA & $0.15 \pm 0.01^{\mathrm{c}}$ & $1.10 \pm 0.01^{\mathrm{c}}$ \\
\hline
\end{tabular}

Means in the same column with different superscript are significantly different at $p<0.05$. CD - control diet, HFD - high-fat diet, HFDVA - high-fat diet with Vernonia amygdalina. 
Ekeleme-Egedigwe, C. A., ljeh, I. I., Okafor, P. N. (2017). Modulatory effects of dietary supplementation by Vernonia amygdalina on high-fat-diet-induced obesity in Wistar rats. Acta Sci. Pol. Technol. Aliment., 16(4), 431-442. http://dx.doi.org/10.17306/J. AFS.2017.0504

Table 7. Effect of CD, HFD and HFDVA diets on insulin, leptin and blood glucose concentrations

\begin{tabular}{lrrc}
\hline \multicolumn{1}{c}{ Groups } & Insulin, ng/ml & Leptin, pg/ml & Blood glucose, mg/dl \\
\hline CD & $0.07 \pm 0.02^{\mathrm{b}}$ & $0.05 \pm 0.01^{\mathrm{b}}$ & $65.40 \pm 5.00^{\mathrm{b}}$ \\
HFD & $0.10 \pm 0.01^{\mathrm{a}}$ & $0.07 \pm 0.04^{\mathrm{a}}$ & $110.0 \pm 4.55^{\mathrm{a}}$ \\
HFDVA & $0.08 \pm 0.01^{\mathrm{b}}$ & $0.05 \pm 0.02^{\mathrm{b}}$ & $60.50 \pm 5.44^{\mathrm{b}}$ \\
\hline
\end{tabular}

Means in the same column with different superscript are significantly different at $p<0.05$. CD - control diet, HFD - high-fat diet, HFDVA - high-fat diet with Vernonia amygdalina.

as shown in Table 7. These results suggest that glucose intolerance seen in HFD fed rats was significantly ameliorated when HFDVA was fed. These results are in agreement with Ong et al. (2011), who demonstrated that $V$. amygdalina decreased blood glucose by increasing GLUT 4 translocation and inhibiting hepatic glucose-6-phosphatase. Ijeh et al. (2013) also reported that diets incorporating VA positively modulated oral glucose tolerance in non-obese rats. Leptin is a circulating fat-derived protein produced by the adipose tissue which could play a key role in appetite control and energy expenditure. In this study, significantly $(p<0.05)$ higher leptin concentrations were observed in rats that were fed HFDs, suggesting the development of leptin resistance as shown in Table 7. Therefore reduction in body weight is possible by means of a decrease in plasma leptin levels. These results are consistent with our previous report on extracts of Vernonia amygdalina restoring leptin sensi- tivity levels in rats (Egedigwe et al., 2016b). Similarly, there was a significant $(p<0.05)$ increase in insulin levels in HFD-fed rats relative to HFDVA, suggesting insulin resistance. Therefore, a decrease in insulin levels in HFDVA could have reversed the high levels observed when animals were fed HFD. This is in agreement with our previous report, where extracts of Vernonia amygdalina reduced insulin levels, thereby restoring insulin sensitivity (Egedigwe et al., 2016b). Figure 1A shows the photomicrograph of the liver section in animals fed CDs, which appears normal with no inflammatory cells. The cords of hepatocytes are well preserved with the cytoplasm unvacuolated, and sinusoids are well demarcated with no fatty infiltration. Figure 1B shows the photomicrograph of the liver section in animals fed HFD, which shows the histologic appearance of hepatic macrovesicular steatosis (fatty infiltration) in the hepatocytes as vacuoles. The arrow shows that the nucleus is almost displaced

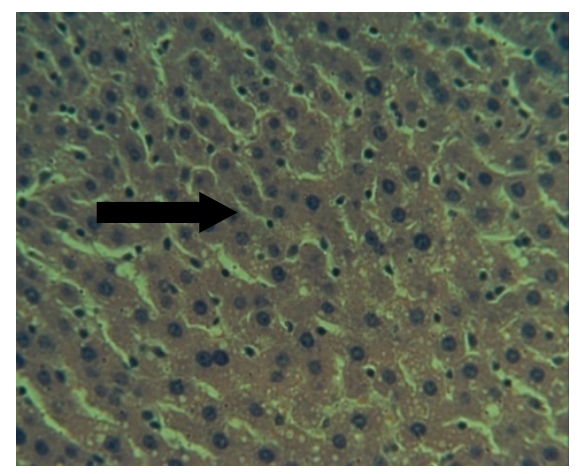

A

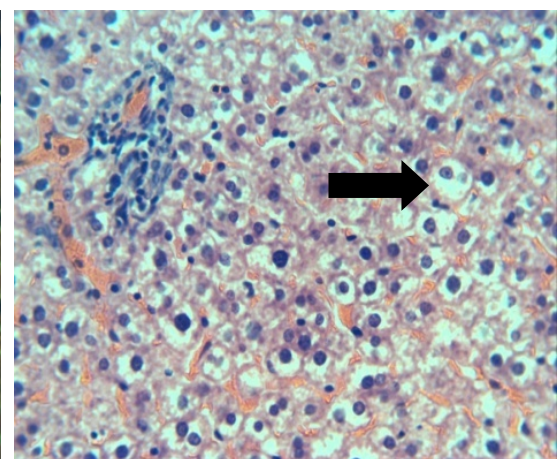

B

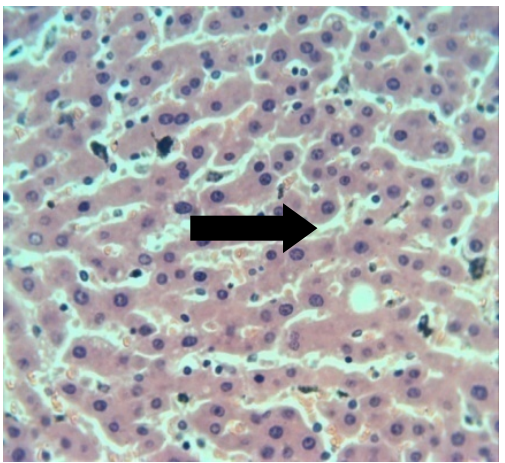

$\mathrm{C}$

Fig. 1. Histological changes of liver in the rats fed diets control, HFD and HFDVA. Each tissue was stained with H\&E (hematoxylin-eosin) and observed microscopically at $\times 400$ magnification: A - control diet, B - HFD (high-fat diet), C HFDVA (high-fat diet with Vernonia amygdalina) 
from the cytoplasm to a corner, therefore pushing the nucleus to the periphery of the cell, giving a characteristic signet ring appearance. The liver section in animals fed HFDVA (C) shows narrow hepatocyte cells which indicate that Vernonia amygdalina leaves incorporated were effective in controlling hepatic steatosis, which is typical in animals that lost weight. This suggests that HFDVA diets reduced excess fat in liver cells or it reversed fatty liver changes as seen in the group fed HFDs. Vernonia amygdalina-supplemented feeding modulated the fatty liver and also reversed the seeming damage by restoring the hepatic enzyme activity. Histhopathological studies of the liver section suggest non-toxicity of VA leaves at the level of dietary incorporation. This is because an enlargement of the liver might be an indicator for pathologic development.

\section{CONCLUSION}

Dietary incorporation of Vernonia amygdalina in high-fat-diet-induced obesity decreased the body weight in Wistar rats, improved lipid metabolism and inhibited fattty infiltration in the liver tissue, thus leading to potent antiobesity effects. The observed effects are likely to be as a result of the rich chest of phytochemicals present in this leafy vegetable. Individuals who are predisposed to obesity could consume this leafy vegetable as part of their diet, which could be beneficial in improving weight loss. The isolation of active principle(s) from this vegetable could indicate the bioactive constituents, which could be responsible for its efficacy in weight loss management.

\section{REFERENCES}

Abbott, R. D., Wilson, P. W., Kannel, W. B., Castelli, W. P. (1988). High density lipoprotein-cholesterol, total cholesterol screening and myocardial infarction. The Framingham Study. Arterioscl. Thromb. Vasc. Biol., 8, 207-211. https://doi.org/10.1161/01.ATV.8.3.207

Abdollahi, M., Afshar-Imani, B. (2003). A review on obesity and weight loss measures. Middle East Pharm., 11, 6-10.

Adaramoye, O. A., Akintayo, O., Achem, J., Fafunso, M. A. (2008). Lipid-lowering effects of methanolic extract of Vernonia amygdalina leaves in rats fed on high cholesterol diet. Vasc. Health Risk Manag., 4(1), 235 241. PMCID: PMC2464769.

Adeneye, A. A., Adeyemi, O. O., Agbaje, E. O. (2010). Anti-obesity and antihyperlipidaemic effect of Hunteria umbellata seed extract in experimental hyperlipidaemia. J. Ethnopharm., 130, 307-314. http://dx.doi. org/10.1016/j.jep.2010.05.009

Agbogidi, O. M., Akpomorine, M. O. (2013). Health and nutritional benefits of bitter leaf (Vernonia amygdalina Del.). Int. J. Appl. Pharm. Sci. BioMed. Sci., 2(3), 164-170.

Akah, P. A., Okafor, C. I. (1992a). Blood sugar lowering effect of Vernonia amygdalina (Del) in an experimental rabbit model. Phytother. Res., 6(3), 171-173. http:// dx.doi.org/10.1002/ptr.2650060318

Akah, P. A., Okafor, C. I. (1992b). Hypoglycaemic effect of Vernonia amygdalina (Del) in experimental rabbits. J. Med. Plants Res., 1, 6-10.

Allain, C. C., Poon, L. S., Chan, C. S., Richmond, W., Fu, P. C. (1974). Enzymatic colorimetric method for cholesterol estimation. Clin. Chim., 20, 470-475. PMID:4818200.

Atangwho, I. J., Ebong, P. E., Eyong, E. U., Eteng, M. U., Uboh, F. E. (2007a). Vernonia amygdalina Del: A potential prophylactic anti-diabetic agent in lipid complication. Global J. Pure Appl. Sci., 18(1), 103-106.

Atangwho, I. J., Ebong, P. E, Egbung, G. E., Eteng, M. U., Eyong, E. U. (2007b). Effect of Vernonia amygdalina Del. on liver function in alloxan-induced hyper glycemic rats. J. Pharm. Bioresour., 4, 25-31. http://dx.doi. org/10.4314/jpb.v4i1.32107

Atangwho, I. J., Edet, E. E., Uti, D. E., Obi, A. U., Asmawi, M. Z., Ahmad, M. (2012). Biochemical and histological impact of Vernonia amygdalina supplemented diet in obese rats. Saudi J. Biol. Sci., 19, 385-392.

Balaji, M., Ganjayi, M. S., Hanuma Kumar, G. E. N., Parim, B. N., Mopuri, R., Dasari, S. (2015). A review on possible therapeutic targets to contain obesity: The role of phytochemicals. Obesity Res. Clin. Pract., 10, 1-18. http://dx.doi.org/10.1016/j.orcp.2015.12.004

Bonsi, M. L. K., Osuji, P. O., Tuah, A. K., Umunna, N. N. (1995). Vernonia amygdalina as a supplement to teff straw (Eragrostis tef) fed to Ethiopian Menz sheep. Agrofor. Syst., 31(3), 229-241. http://dx.doi. org/10.1007/BF00712076

Bordia, A., Verma, S. K. (1998). Effect of Celastrus paniculatus wild oil (Bravobol) on blood lipids in patients of coronary. Antiseptic, 95(4), 112-114.

Charradi, K., Elkahoui, S., Karkouch, I., Limama, F., Ben Hassine, F., El May, M. V. (2014) Protective effect of grape seed and skin extract against high-fat-diet-induced 
liver steatosis and zinc depletion in rat. Dig. Dis. Sci., 59(8), 1768-1778. http://dx.doi.org/10.1007/s10620014-3128-0

Chukwuonye, I. I., Chuku, A., John, C., Ohagwu, K. A., Imoh, M. E., Isa, S. E., ..., Oviasu, E. (2013a). Prevalence of overweight and obesity in adult Nigerians a systematic review. Diab. Metab. Syndr. Obes. Targets Therap., 6, 43-47. http://dx.doi.org/10.2147/DMSO. S38626

Chukwuonye, I. I., Chuku, A., Okpechi, I. G., Onyeonoro, U. U., Madukwe, O. O., Okafor, G. O. C., Ogah, O. S. (2013b). Socio-economic status and obesity in Abia State, South East Nigeria. Diab. Metab. Syndr. Obesit. Targets Therap., 6, 371-378. https://doi.org/10.2147/ DMSO.S44426

Cromwell, W. C., Otvos, J. D. (2004). Low-density lipoprotein particles number and risk for cardiovascular disease. Curr. Atheroscl. Rep., 6, 381-387. http://dx.doi. org/10.1007/s11883-004-0050-5

D’Orazio, P., Burnett, R. W., Fogh-Andersen, N., Jacobs, E., Kuwa, K., Kulpmann, W. R., ..., Okorodudu, A. O. (2005). Approved International Federation of Clinical Chemistry (IFCC) recommendation on reporting results for blood glucose. Clin. Chem., 51(9), 1573-1576. http://dx.doi.org/10.1373/clinchem.2005.051979

Egedigwe, C. A. (2010). Effect of dietary incorporation of Vernonia amygdalina and Vernonia colorata on blood lipid profile and relative organ weights in Albino rats. M.Sc. Dissertation in Department of Biochemistry, MOUAU, Nigeria.

Egedigwe, C. A. (2015). Evaluation of possible body fat regulatory mechanisms of crude extracts and fractions from leaves of Vernonia amygdalina in Wistar rats. Ph.D. Dissertation in the Department of Biochemistry, MOUAU, Nigeria.

Egedigwe, C. A., Ijeh, I. I. (2010a). Body and organ weight changes following dietary incorporation of Vernonia colorata and Vernonia amygdalina Del in albino rats. Niger. J. Nutr. Sci., 31(2), 58-61. http://dx.doi. org/10.4314/njns.v31i2.63917

Egedigwe, C. A., Ijeh, I. I. (2010b). Lipid changes in albino rats fed diets incorporating Vernonia amygdalina Del leaves. Niger. J. Biochem. Mol. Biol., 25(2), 105-110.

Egedigwe, C. A., Ejike, C. E. C. C., Ijeh, I. I., Herbert, U., Onwuka, G. I., Asumugha, V. U. (2016a). Anti-obesity potentials of aqueous and methanol extracts of Vernonia amygdalina Del. leaves in high-fat diet fed rats. Afr. J. Trad. Compl. Altern. Med., 13(2), 86-93. http://dx.doi. org/10.4314/ajtcam.v13i2.11
Egedigwe, C. A., Ijeh, I. I., Okafor, P. N., Ejike, Ch. E. C. C. (2016b). Aqueous and methanol extracts of Vernonia amygdalina leaves exert their anti-obesity effects through the modulation of appetite-regulatory hormones. Pharm. Biol., 54, 12, 1-6. http://dx.doi.org/10.1 080/13880209.2016.1216135

Farombi, E. O., Owoeye, O. (2011). Antioxidative and chemopreventive properties of Vernonia amygdalina and Garcinia biflavonoid. Int. J. Environ. Res. Public Health, 8(6), 2533-2555. http://dx.doi.org/10.3390/ ijerph8062533

Francis, G., Kerem, Z., Makkar, H. P. Becker, K. (2002). The biological action of saponins in animal systems: a review. Brit. J. Nutr., 88, 6, 587-605. http://dx.doi. org/10.1079/BJN2002725

Friedewald, W. T., Levy, R. I., Frederickson, D. S. (1972). Estimation of the concentration of LDL cholesterol in plasma, without the use of the preparative ultra-centrifuge. Clin. Chem., 18, 499-502. PMID: 4337382.

Ghibaudi, L., Cook, J., Farley, C., van Heek, M., Hwa, J. J. (2002). Fat intake affects adiposity, comorbidity factors and energy metabolism of Sprague-Dawley rats. Obesity Res., 10(9), 956-963. http://dx.doi.org/10.1038/ oby. 2002.130

Han, L. K., Kimura, Y., Okuda, H. (2005a). Anti-obesity effects of natural products. Stud. Nat. Prod. Chem., 30, 79-109.

Han, L. K., Zheng, Y. N., Yoshikawa, M., Okuda, H., Kimura, Y. (2005b). Anti-obesity effects of chikusetsusaponins isolated from Panax japonicus rhizomes. BMC Compl. Altern. Med., 5(9), 1-10. http://dx.doi. org/10.1186/1472-6882-5-9

Han L. K., Zheng, Y. N., Xu, B. J., Okuda, H., Kimura, Y. (2002). Saponins from Platycodi radix ameliorate high-fat-diet-induced obesity in mice. J. Nutr., 132, 22412245. PMID: 12163669.

Harrold, J. A., Williams, G., Widdowson, P. S. (2000). Early leptin response to a palatable diet predicts dietary obesity in rats: Key role of melanocortin- 4 receptors in the ventromedial hypothalamic nucleus. J. Neurochem., 74, 1224-1228.

Hasani-Ranjbar, S., Larijani, B., Abdollahi, M. (2008). A systematic review of Iranian medicinal plants useful in diabetes mellitus. Arch. Med. Sci., 4, 285-292.

Ibrahim, N. D. G., Abdurahman, G., Ibrahim, E. M. (2000). Histological studies on the effects of chronic feeding of Vernonia amygdalina Del. leaves on rats. Niger. J. Surgery Res., 2, 68-74. http://dx.doi.org/10.4314/njsr. v2i2.12188 
Ekeleme-Egedigwe, C. A., ljeh, I. I., Okafor, P. N. (2017). Modulatory effects of dietary supplementation by Vernonia amygdalina on high-fat-diet-induced obesity in Wistar rats. Acta Sci. Pol. Technol. Aliment., 16(4), 431-442. http://dx.doi.org/10.17306/J. AFS.2017.0504

Igile, G., Oleszek, W., Burda, S., Jurzysta, M. (1995). Nutritional assessment of Vernonia amygdalina leaves in growing mice. J. Agric. Food Chem., 43, 2162-2166.

Ijeh, I. I., Egedigwe, A. C., Inyang, E. I., Emmanuel, G. (2014). Hypolipidaemic effects and body weight changes of male Wistar rats administered crude saponin extracts from Vernonia amydalina and Vernonia colorata leaves. Niger. J. Biochem. Molecular Biol., 29(1), 35-43.

Ijeh, I. I., Amadi, I. P., Ejike, C. E. C. C. (2013). Improvement of glucose tolerance in rats fed with diets containing Vernonia amygdalina. Biokemistri, 25(1), 1-5.

Ijeh, I. I., Akomas, S. C. (2005). Effect of oral administration of ethanolic extract of Vernonia amygdalina on the exocrine functions in weanling rabbits. Proceedings of the $30^{\text {th }}$ Annual Conference of the Nigerian Society for Animal Production, 30.

Ijeh, I. I., Ejike, C. E. C. C. (2011). Current perspectives on the medicinal potentials of Vernonia amygdalina Del. J. Med. Plants Res., 5, 1051-1061.

Ijeh, I. I., Obidoa, O. (2001). Effect of dietary incorporation of two varieties of Vernonia amygdalina on mean relative organ weight of weanling rabbits. Niger. J. Biochem. Molec. Biol., 16, 13.

Ijeh, I. I., Nwugo,V. O., Obidoa, O. (1996). Comparative studies on the nutritive, phytochemical and antimicrobial properties of two varieties of Vernonia amygdalina. Plant Prod. Res. Commun., 1, 71-75.

Jenkin, D. J. A., Jenkin, A. L., Wolever, T. M. S., Rao, A. V., Thompson, L. U. (1986). Fibre and stang foods: gut function and implication in disease. Am. J. Gastroenter., 81, 920-930.

Karu, N., Reifen, R., Kerem, Z. (2007). Weight gain reduction in mice fed Panax ginseng saponin, a pancreatic lipase inhibitor. J. Agric. Food Chem., 55, 2824-2828. http://dx.doi.org/10.1021/jf0628025

Komolafe, K., Olaleye, M. T., Fasan, T. I., Elekofehinti, O. O., Saliu, J. A., Akindahunsi, A. A. (2013). Lowering effect of Parkia biglobosa leaf saponins in Triton-X1339. -induced hyperlipidemic rats. Res. J. Pharm. Biol. Chem. Sci., 4(1), 576-585.

Kritchevsky, D. (1977). Dietary fibre and other dietary factors in hypercholesterolemia. Am. J. Clin. Nutr., 30, 979-984.

Lee, M. O. (1929). Determination of the surface area of the white rat with its application to the expression of metabolic results. Am. J. Physiol., 89(1), 24-33.

Lee, S. O., Simons, A. L., Murphy, P. A., Hendrich, S. (2005). Soya saponins lowered plasma cholesterol and increased fecal bile acids in female golden Syrian hamsters. Exp. Biol. Med., 230, 472-478. PMID: 15985622.
Lopes-Virella, M. F., Stone, P., Ellis, S. (1977). Cholesterol determination in high density lipoprotein separated by three different methods. Clin. Chem., 23, 882 PMID:192488.

Mistry, K. G., Deshpande, S. S., Shah, G. B., Gohil, P. V. (2011). Effect of sarpogrelate in high-fat-diet-induced obesity in rats. Asian J. Pharm. Biol. Res., 441-446.

Mohan, H. (2007). Pathology practical book (pp. 126-127). 2nd ed. New Delhi: Jaypee Brothers Publ.

Moro, C. O., Basile, G. (2000). Obesity and medicinal plants. Fitoterapia, 71, S73-S82. PMID: 10930716.

Nwanjo, H. U. (2005). Efficacy of aqueous leaf extract of Vernonia amygdalina on plasma lipoproteins and oxidative status in diabetic rat model. Nigeria J. Physiol. Sci., 20(1-2), 39-42.

NIH Publications 80-23 revised (1996). Guide for the care and use of laboratory animals. Betheseda, USA: Office of Science and Health Reports. MD 20205.

Oakenfull, D. G., Sidhu, G. S. (1989). Saponins. In P. R. Cheeke (ed.), Toxicants of plant origin. 2. Glycosides (pp. 97-143). Boca Raton, Florida: CRC Press.

Ong, K. W., Hsu, A., Song, L., Huang, D., Tan, B. K. (2011). Polyphenols-rich Vernonia amygdalina shows anti-diabetic effects in streptozotocin-induced diabetic rats. J. Ethnopharm., 133(2), 598-607. http://dx.doi. org/10.1016/j.jep.2010.10.046

Ong, S. L., Nalamolu, K. R., Lai, H. Y. (2017). Potential lipidlowering effects of Eleusine indica (L.) Gaertn. extract on high-fat-diet-induced hyperlipidemic rats. Pharmacogn. Mag., 13, 49, 1-9. http://dx.doi.org/10.4103/0973-1296. 203986

Rayalam, S., Della-Fera, M. A., Baile, C. A. (2008). Phytochemicals and regulation of the adipocyte life cycle. J. Nutr. Biochem., 19, 717-726. http://dx.doi. org/10.1016/j.jnutbio.2007.12.007

Singh, D. (2006). Principles and techniques in histology micrograph and photomicrography. 2nd ed. (pp. 19-54). New Delhi, India: CBS Publ. Distrib.

Teguia, A., Tchoumboue, J., Mayaka, B. T., Tnakou, C. M. (1993). The growth of broiler chickens as affected by the replacement of graded levels of maize by sweet potato leaves (Ipomoea batatas) or Ndole (Vernonia spp.) in the finisher diet. Anim. Feed Sci. Techn., 40, 233-237.

Thielecke, F., Boschmann, M. (2009). The potential role of green tea catechins in the prevention of the metabolic syndrome - A review. Phytochemistry, 70, 11-24. http:// dx.doi.org/10.1016/j.phytochem.2008.11.011

Tietz, N. W. (1990). Clinical guide to Laboratory tests. $2^{\text {nd }}$ ed. (pp. 554-556). Philadelphia, USA: WB Saunders Comp. 
Topping, D. L., Storer, G. B., Calvert, G. G. (1980). Effects of dietary saponins on faecal bile acids and neutral sterols, plasma lipid and lipid turnover in the pig. Am. J. Clin. Nutr., 33(4), 783-786. PMID: 7361696.

WHO (1999). Radix ginseng. In WHO monographs on selected medicinal plants (pp. 168-162). Geneva: World Health Organization.

WHO (2012). World health statistics. Geneva: WHO. Retrieved from: http://www.who.int/gho/publications/ world_health_statistics/EN_WHS2012_Full.pdf.

Wolfram, S., Wang Y., Thielecke, F. (2006). Anti-obesity effects of green tea: from bedside to bench. Molec. Nutr. Food Res., 50, 176-187. http://dx.doi.org/10.1002/ mnfr.200500102

Yokozawa, T., Cho, E. J., Sasaki, S., Satoh, A., Okamoto, T., Sei, Y. (2006). The protective role of Chinese prescription Kangenkaryu extract on diet-induced hypercholesterolemia in rats. Biol. Pharm. Bull., 29, 760-765.

Yoshizumi, K., Hirano, K., Ando, H., Hirai, Y., Ida, Y., Tsuji, T., ..., Terao, J. (2006). Lupane-type saponins from leaves of Acanthopanax sessiliflorus and their inhibitory activity on pancreatic lipase. J. Agric. Food Chem., 54, 335-341.

Yun, J. W. (2010). Possible anti-obesity therapeutics from nature - A review. Phytochem. J., 71, 1625-1641. http:// dx.doi.org/10.1016/j.phytochem.2010.07.011

Zhao, H. L., Harding, S. V., Marinangeli, C. P., Kim, Y. S., Jones, P. J. (2008). Hypocholesterolemic and anti-obesity effects of saponins from Platycodon grandiflorum in hamsters fed atherogenic diets. J. Food Sci., 73(8), 195-200. http://dx.doi.org/10.1111/j.1750-3841.2008.00915.x 